\title{
KEMAMPUAN MEMBACA DAN MENULIS MAHASISWA ASING MENGGUNAKAN BAHASA DI UIN WALISONGO SEMARANG
}

\author{
Maya Rini Handayani \\ mayarinihandayani@walisongo.ac.id
}

\begin{abstract}
Abstrak
Artikel ini membahas mengenai kemampuan membaca dan menulis responden yang merupakan mahasiswa asing di UIN Walisongo Semarang. Responden berasal dari wilayah kelompok propinsi Thailand Selatan. Kemampuan membaca dan menulis responden diukur menggunakan indikator bahasa Indonesia (Bahasa) yaitu kemampuan membaca dan menulis. Responden berjumlah 37 orang, terdiri dari 25 mahasiswi dan 12 mahasiswa yang tersebar di 3 fakultas di UIN Walisongo Semarang. Responden berusia antara 20 hingga 28 tahun dari angkatan 2012 hingga 2016. Bahasa asli dari responden adalah bahasa Melayu. Bahasa kedua yang dikuasai responden adalah bahasa Thailand. Responden belum cukup mempunyai bekal kemampuan Bahasa sebelum tiba di Indonesia. Pengumpulan data pada artikel ini menggunakan kuisioner. Hasil temuan yang diperoleh untuk indikator membaca adalah mean atau rata-rata responden dalam membaca tulisan Bahasa berada pada angka 22. Angka tersebut berada di antara interval 21 - 22 yang menunjuk pada kategori sedang. Sedangkan hasil temuan untuk indikator menulis adalah mean berada pada angka 25. Angka 25 terletak di antara interval $24-25$ yang menunjuk pada kategori sedang. Kategori ini menggunakan interval standar lima yaitu sangat tinggi, tinggi, sedang, rendah dan sangat rendah. Kesimpulan yang dapat diperoleh dalam artikel ini adalah baik kemampuan membaca dan menulis responden menggunakan Bahasa berada pada kategori sedang.

Kata kunci: membaca, menulis Bahasa, mahasiswa Thailand Selatan
\end{abstract}




\begin{abstract}
This article discusses the writing and reading skills of South Thailand students at UIN Walisongo Semarang. The respondents were from the province of South Thailand, their skills were measured by using an indicator of ability to write and speak Bahasa. They were 37 students from 2012 till 2016, who aged between 20 to 28 years old. The 12 students were males while the rest were female students. These students were spread across 3 faculties. Their original language was Malay whereas the second one was Thai. They actually did not have adequate language skills preparation before having come to Indonesia. Data were collected by using questionnaires with average skills of reading Bahasa was 22. The score of 22 is located between 21-22 interval, which it refers to medium category. While the average of writing skills was in 25 (in a medium category as well). The conclusion that can be obtained in this article is that both the ability to read and write respondents using the language is in the medium category.
\end{abstract}

Keywords:reading, writing Bahasa, students of South Thailand

\title{
A. Pendahuluan
}

Perubahan statuta dari IAIN (Institut Agama Islam Negeri) menjadi UIN (Universitas Islam Negeri) membuat banyak calon mahasiswa/i di Indonesia tertarik untuk menempuh pendidikan di UIN Walisongo Semarang. Didukung dengan bertambahnya jumlah fakultas menjadi delapan, daya minat calon mahasiswa menjadi semakin besar. Ke delapan fakultas tersebut adalah fakultas Dakwah dan Komunikasi (FDK), fakultas Ilmu Tarbiyah dan Keguruan (FITK), fakultas Syariah dan Hukum (FSH), fakultas Ushuluddin dan Humaniora (FUHUM), fakultas Ekonomi dan Bisnis Islam (FEBI), fakultas Psikologi dan Kesehatan (FPK), fakultas Sains dan Teknologi (FST) dan fakultas Ilmu Sosial dan Ilmu Politik (FISIP). Ketertarikan untuk belajar di UIN Walisongo Semarang ternyata tidak hanya menarik minat calon mahasiswa/i Indonesia namun juga negara tetangga untuk melanjutkan pendidikan. Salah satu negara tetangga tersebut adalah Thailand khususnya kelompok propinsi Thailand Selatan.

Dari kedelapan fakultas tersebut, ada tiga fakultas yang menjadi minat mahasiswa Thailand Selatan, yaitu FDK, FITK, dan FSH. Ketertarikan mahasiswa Thailand Selatan terhadap ketiga fakultas tersebut disebabkan para mahasiswa sudah menempuh pendidikan sesuai dengan jurusan di fakultas yang sama di negaranya. Pendidikan yang telah diambil sebelum ke UIN Walisongo masih bertaraf diploma 3 (D3). Mahasiswa Thailand Selatan berkeinginan untuk melanjutkan ke jenjang yang lebih tinggi yaitu strata 1 (S1) dengan bidang keilmuan yang linier. Harapannya ketika kembali ke Thailand Selatan, ilmu linier yang diperoleh di UIN Walisongo Semarang dapat dipraktikkan dan disebarkan ke sesama rekan-rekan muslim dinegaranya terutama di kelompok propinsi Thailand Selatan.

Kelompok propinsi Thailand Selatan secara geografis dekat dengan negara Malaysia. Kondisi geografis seperti ini menyebabkan bercampurnya budaya dan bahasa oleh kedua negara. Faktor 
inilah yang menyebabkan mahasiswa kelompok propinsi Thailand Selatan lebih menguasai bahasa Melayu daripada bahasa Indonesia. Meskipun bahasa Melayu serumpun dengan bahasa Indonesia (untuk selanjutnya dalam artikel ini ditulis dengan kata Bahasa), tetap memiliki perbedaan yang besar dalam bentuk bacaan dan tulisannya. Hal tersebut menjadi faktor yang menarik untuk dibahas dalam artikel ini. Penulis ingin mengetahui seberapa besar kemampuan mahasiswa kelompok propinsi Thailand Selatan dalam membaca dan menulis Bahasa.

\section{B. Metode Penelitian}

Artikel ini sebenarnya adalah bagian dari sebuah penelitian yang sudah dilakukan oleh penulis pada tahun 2017. Penelitian tersebut membahas mengenai pengaruh kemampuan berbahasa Indonesia terhadap keberhasilan studi mahasiswa Thailand Selatan di UIN Walisongo Semarang. Subjek penelitian adalah mahasiswa dari kelompok propinsi Thailand Selatan, terutama wilayah propinsi Pattani, Satun, Yala dan Narathiwat.

Dikarenakan artikel ini bagian dari sebuah penelitian maka metode penelitian pada artikel ini mengikuti penelitian asli. Metode penelitian yang digunakan adalah kuantitatif deskriptif. Pengumpulan data menggunakan kuisioner atau angket yang berpedoman pada indikator yang digunakan. Populasi pada artikel adalah seluruh mahasiswa kelompok propinsi Thailand Selatan angkatan 2012 hingga 2016. Populasi merupakan keseluruhan atribut dapat berupa objek atau kejadian yang menjadi fokus penelitian ${ }^{1}$. Jika berkaitan dengan populasi maka penelitian ini termasuk dalam penelitian populasi. Hal ini didasarkan pada pendapat Arikunto bahwa jumlah sampel dalam penelitian apabila populasi kurang dari 100, lebih baik diambil semua sehingga penelitiannya merupakan penelitian populasi. Selanjutnya, jika jumlah subjeknya lebih dari 100 dapat diambil sampel antara 10-15\% atau 20-25\% dari jumlah populasi ${ }^{2}$. Metode pengambilan sampel dalam penelitian ini (sampel adalah sebagian atau wakil populasi yang akan diteliti) adalah metode sampling jenuh. Sampling jenuh artinya semua populasi diambil sebagai responden. Hal ini disebabkan jumlah populasi hanya 37 orang yang mana kurang dari 100 orang. Metode sampling jenuh milik Sugiyono sama dengan pendapat Arikunto yang mengatakan jika populasi kurang dari 100 maka lebih baik diambil semua sehingga penelitiannya merupakan penelitian populasi ${ }^{3}$.

\section{Pembahasan}

\section{Sekilas Thailand Selatan}

Secara administratif, Kerajaan Thailand dibagi menjadi 76 propinsi (changwat). Ke 76 propinsi tersebut dikelompokkan ke dalam lima kelompok propinsi yaitu Thailand Utara, Thailand Timur, Thailand Selatan, Thailand Timur Laut dan Thailand Tengah. Dari kelima kelompok propinsi tersebut, subjek penelitian berasal dari wilayah Thailand Selatan. Nama

1 Muri. Yusuf [2014] Metode Penulisan Kuantitatif, Kualitatif dan Penulisan Gabungan. Jakarta: Prenada Media Group, hal 144

2 Suharsimi. Arikunto [2002] Prosedur Penulisan Suatu Pendekatan Praktek. Jakarta: PT Renaka Cipta, hal 112

3 Sugiyono. [2005] Statistika untuk Penelitian. Bandung: CV. Alfabeta 
tiap propinsi berasal dari nama ibu kota propinsinya ${ }^{4}$. Propinsi Thailand Selatan terdiri dari Chumphon, Krabi, Nakhon Si Thammarat, Narathiwat, Pattani, Phang Nga, Phattalung,

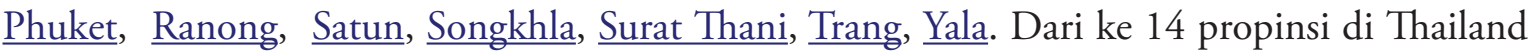
Selatan tersebut, empat diantaranya yaitu Pattani, Yala, Narathiwat dan Satun berpenduduk mayoritas beragama Islam. Jumlah muslim di Thailand adalah tiga juta jiwa dengan sebanyak 710.906 jiwa adalah muslim Melayu'.

Pattani ( ปัตตานี) merupakan salah satu propinsi (changwat) di selatan Thailand. Pattani adalah nama sebuah ibu kota dari sebuah propinsi. Propinsi ini berbatasan dengan Malaysia. Konon nama Pattani berasal dari bahasa Melayu yaitu kata "petani”. Ada pula yang berpendapat, Pattani berasal dari kata "Pattani" dalam bahasa Pattani Melayu. Kata "Pattani" mempunyai arti pantai ini ${ }^{6}$. Propinsi-propinsi yang bertetangga (dari arah Selatan Tenggara searah jarum jam) adalah Narathiwat (Menara), Yala (Jala) dan Songkhla (Senggora). Masyarakat Melayu setempat menyebut propinsi Pattani dengan sebutan Pattani Darussalam atau Pattani Raya.

Wilayah Pattani sendiri terbagi menjadi 12 kawasan pentadbiran (amphoe), dibagi lagi menjadi 115 daerah swapraja (tambon) dan 629 buah kampung atau biasa disebut mubaan ${ }^{7}$. Ke 12 wilayah tersebut adalah 1) Mueang Pattani dalam bahasa Thailand มืองปัตตานี dan dalam bahasa Melayu disebut Pattani, 2) Khok Pho dalam bahasa Thailand โคกโพธิ์, 3) Nong Chik dalam bahasa Thailand หนองจิก, 4) Panare dalam bahasa Thailand ปะนาเระ dan bahasa Melayu Panarek, 5) Mayo dalam bahasa Thailand มายอ dan bahasa Melayu Maja, 6) Thung Yang Daeng dalam bahasa Thailand ทุ่งยางแดง, 7) Sai Buri dalam bahasa Thailand สายบุรี dan bahasa Melayu Selindung Bayu, Telube, 8) Mai Kaen dalam bahasa Thailand ไม้แก่น, 9) Yaring dalam bahasa Thailand ยะหริ่ง dan bahasa Melayu Jaring, Jamu, 10) Yarang dalam bahasa Thailand ยะรัง dan bahasa Melayu Cegar, 11) Kapho dalam bahasa Thailand กะพ้อ dan terakhir 12) Mae Lan dalam bahasa Thailand แม่ลาน.

\section{Subjek Penelitian}

Dalam penelitian ini populasinya adalah seluruh mahasiswa kelompok propinsi Thailand Selatan angkatan 2012 hingga 2016. Subjek penelitian (selanjutnya disebut responden) tersebar di tiga fakultas yaitu FDK, FSH, dan FITK. Jumlah mahasiswa yang menjadi responden sebanyak 37 . Ke 37 responden terdiri dari 25 mahasiswi dan 12 mahasiswa dengan rentang usia berkisar 20 hingga 28 tahun. Mahasiswa FDK berjumlah 6 orang, FITK berjumlah 27 orang dan mahasiswa FSH sebanyak 4 orang. ${ }^{8}$

4 Maya Rini. Handayani [2014] The Role of Information Technology in Islamic Da'wa Student Development at Pondok Bantan Nakhon Si Thammarat Southern Thailand. ISBN 978-602-17171-9-6. page 4

5 Maya Rini. Handayani [2014] The Role of Information Technology in Islamic Da'wa Student Development at Pondok Bantan Nakhon Si Thammarat Southern Thailand. ISBN 978-602-17171-9-6. page 5

6 Anonim. [2017] Pattani Thailand, https://en.wikipedia.org/wiki/Pattani, Thailand, diakses 24 Februari 2017

7 Anonim. [2017] Wilayah Pattani, https://ms.wikipedia.org/wiki/Wilayah Pattani, pada 18 Oktober 2017

8 Maya Rini. Handayani [2017] Pengaruh Kemampuan Berbahasa Indonesia terhadap Keberhasilan Studi Mahasiswa Pattani Thailand Selatan di UIN Walisongo Semarang. Laporan Penelitian Individual dibiayai dengan Anggaran DIPA LP2M UIN Walisongo Semarang tahun 2017. hal. 37 
Dari ke 12 wilayah propinsi Pattani, responden pada penelitian ini berasal dari daerah Yarang (5 responden), Nong Chik (5 responden), Khok Pho (2 responden), Mueang Pattani (9 responden), Sai Buri (1 responden), Panarek (1 responden), Yaring (1 responden). Sisa responden berasal dari propinsi lain, yaitu Satun (2 responden), Yala (5 responden), Songkhla (2 responden), dan Narathiwat (4 responden). Satun adalah salah satu propinsi yang berdekatan dengan Trang, Phattalung dan Songkhla. Sebanyak 67,8\% penduduk Satun adalah Muslim dan $31,9 \%$ adalah Buddha. Mayoritas rakyat Satun adalah orang Melayu?

Yala dalam bahasa Thailand ยะลา adalah propinsi (changwat) Thailand yang terletak di bagian paling selatan. Wilayah-wilayah yang berdekatan dengan Yala adalah Songkhla, Pattani dan Narathiwat. Masyarakat Melayu setempat menyebut wilayah Yala dengan nama Jolor. Penduduk Yala lebih kurang 68,9\% adalah Muslim. Dari 68,9\% tersebut sebanyak $66,1 \%$ nya adalah bangsa Melayu ${ }^{10}$. Bahasa ibu yang digunakan oleh ke empat propinsi tersebut adalah Bahasa Melayu Pattani yang berbeda dengan Bahasa Melayu apalagi Bahasa Indonesia.

\section{Analisis dan Pembahasan}

Pada artikel ini kemampuan membaca dan menulis responden diukur dengan menggunakan indikator membaca dan menulis Bahasa. Keberhasilan kemampuan berBahasa maksudnya adalah mengukur seberapa jauh responden dalam membaca dan menulis tulisan menggunakan Bahasa. Kemampuan membaca dan menulis diukur dengan menggunakan pernyataan di kuisioner. Untuk kemampuan membaca ada 8 butir, sedangkan kemampuan menulis menggunakan 9 butir pernyataan. Berikut ini akan diuraikan tentang analisa kemampuan baik membaca dan menulis menggunakan analisa deskriptif.

\section{a. Analisa Kemampuan Membaca}

Ke 8 butir pernyataan untuk kemampuan membaca terbagi menjadi 4 butir favorable dan 4 butir unfavorable. Butir favorable ditunjukkan pada pernyataan butir 10, 13, 15, dan 17. Butir unfavorable ditunjukkan pada butir 11, 12, 14, dan $16^{11}$. Berikut ini adalah analisis kuantitatif deskriptif berdasarkan jawaban responden untuk setiap butir.

\section{Butir 10 (Fav)}

Butir 10 merupakan pernyataan positif yang ditujukan ke responden. Tujuan pernyataan untuk mengetahui apakah responden selalu membaca dan menghafalkan kosa kata Bahasa setiap hari. Dari hasil pengolahan SPSS untuk butir 10 menunjukkan sebanyak 29.7\% atau 11 responden memilih jawaban setuju. Lebih dari separuh responden yaitu sebanyak $54.1 \%$ atau 20 responden memilih jawaban tidak setuju. Sebanyak 16.2\% atau 6 responden memilih jawaban sangat tidak setuju, sedangkan jawaban sangat setuju tidak ada seorangpun responden

9 Anonim [2017] Propinsi Satun. https://id.wikipedia.org/wiki/Propinsi Satun, pada 18 Oktober 2017 10 Anonim [2017] Propinsi Yala. https://id.wikipedia.org/wiki/Propinsi Yala, pada 18 Oktober 2017

11 Maya Rini. Handayani [2017] Pengaruh Kemampuan Berbahasa Indonesia terhadap Keberhasilan Studi Mahasiswa Pattani Thailand Selatan di UIN Walisongo Semarang. Laporan Penelitian Individual dibiayai dengan Anggaran DIPA LP2M UIN Walisongo Semarang tahun 2017. hal. 29 
yang memilih. Total dari ketiga jawaban adalah 100\%, artinya semua responden menjawab butir 10 dan valid datanya. Kesimpulan bahwa lebih dari separuh responden yaitu 54.05\% setuju dengan pernyataan butir 10 kuisioner. Artinya lebih dari separuh responden mengatakan responden membaca dan menghafalkan kosa kata Bahasa setiap hari.

\section{Butir 11 (Unfav)}

Butir 11 merupakan pernyataan negatif yang ditujukan ke responden. Tujuan pernyataan untuk mengetahui apakah responden tidak paham jika membaca kalimat atau tulisan Bahasa yang panjang (bukan kalimat SPOK sederhana). Persentase dari jumlah responden untuk butir 11 menunjukkan sebanyak $5.4 \%$ atau 2 responden memilih jawaban sangat setuju. Sebanyak 43.2\% atau 16 responden memilih jawaban setuju. Lebih dari separuh responden yaitu sebanyak $51.4 \%$ atau 19 responden memilih jawaban tidak setuju, sedangkan jawaban sangat tidak setuju tidak ada seorangpun yang memilih. Total dari ketiga jawaban adalah 100\%, artinya semua responden menjawab butir 11 dan valid datanya. Kesimpulan yang dapat diambil adalah lebih dari separuh responden yaitu sebanyak $51.35 \%$ tidak setuju dengan pernyataan butir 11 kuisioner. Artinya lebih dari separuh responden paham jika membaca kalimat atau tulisan Bahasa yang panjang (bukan kalimat SPOK sederhana).

\section{Butir 12 (Unfav)}

Butir 12 merupakan pernyataan negatif yang ditujukan ke responden. Tujuan pernyataan untuk mengetahui apakah responden sering lupa dengan kosa kata yang sudah di baca dan dihapalkan. Persentase responden terhadap butir 12 memperlihatkan bahwa $10.8 \%$ atau 4 responden memilih jawaban sangat setuju. Sebanyak 35.1\% atau 13 responden memilih jawaban setuju. Sebanyak 48.6\% atau 18 responden memilih jawaban tidak setuju, sedangkan sangat tidak setuju dipilih 2 responden atau 5.4\%. Total keempat jawaban adalah 100\%, artinya semua responden menjawab butir 12 dan valid datanya. Kesimpulannya adalah sebanyak 48.65\% tidak setuju dengan pernyataan butir 12 kuisioner. Artinya hampir dari separuh responden tidak lupa dengan baik kosa kata yang sudah di baca dan dihapalkan.

\section{Butir 13 (Fav)}

Butir 13 merupakan pernyataan positif yang ditujukan ke responden. Tujuan pernyataan untuk mengetahui apakah responden selalu belajar atau membaca buku kuliah terlebih dahulu sebelum perkuliahan di mulai. Sebanyak $2.7 \%$ atau 1 responden memilih jawaban sangat setuju. Sebanyak $13.5 \%$ atau 5 responden memilih jawaban setuju. Lebih dari separuh reponden yaitu $64.9 \%$ atau 24 responden memilih jawaban tidak setuju, sedangkan $18.9 \%$ atau 7 responden memilih jawaban sangat tidak setuju. Total dari keempat jawaban adalah 100\%, artinya semua responden menjawab butir 13 dan valid datanya. Kesimpulannya adalah sebanyak 64.86\% atau lebih dari separuh responden tidak setuju dengan pernyataan butir 13 kuisioner. Artinya lebih dari separuh responden tidak selalu belajar atau membaca buku kuliah terlebih dahulu sebelum perkuliahan di mulai. 


\section{Butir 14 (Unfav)}

Butir 14 merupakan pernyataan negatif yang ditujukan ke responden. Tujuan pernyataan untuk mengetahui apakah responden tidak membaca ulang materi mata kuliah di rumah/kos setelah perkuliahan usai. Dua responden atau 5.4\% memilih jawaban sangat setuju. Sebanyak $16.2 \%$ atau 6 responden memilih jawaban setuju. Lebih dari separuh responden memilih jawaban tidak setuju, yaitu sebanyak $62.2 \%$ atau 23 responden. Sedangkan sangat tidak setuju dipilih sebanyak 16.2\% atau 6 responden. Total dari keempat jawaban adalah 100\%, artinya semua responden menjawab butir 14 dan valid datanya. Sebanyak $62.16 \%$ atau lebih dari separuh responden tidak setuju dengan pernyataan butir 14 kuisioner. Kesimpulannya, lebih dari separuh responden mengatakan membaca ulang materi mata kuliah di rumah/kos setelah perkuliahan usai.

\section{Butir 15 (Fav)}

Butir 15 merupakan pernyataan positif yang ditujukan ke responden. Tujuan pernyataan untuk mengetahui apakah responden sering membaca buku teks Bahasa. Sebanyak 5.4\% atau 2 responden memilih jawaban setuju. Sebanyak $70.3 \%$ atau 26 responden (hampir tiga perempat responden) memilih jawaban tidak setuju. Sebanyak $24.3 \%$ atau 8 responden memilih jawaban sangat tidak setuju, sedangkan jawaban sangat setuju tidak ada seorang respondenpun yang memilih. Total dari ketiga jawaban adalah $100 \%$, artinya semua responden menjawab butir 15 dan valid datanya. Kesimpulannya bahwa hampir tiga per empat responden yaitu sebanyak $70.27 \%$ menyatakan tidak setuju dengan pernyataan butir 15 kuisioner. Artinya hampir tiga per empat responden tidak sering membaca buku teks berbahasa Indonesia.

\section{Butir 16 (Unfav)}

Butir 16 merupakan pernyataan negatif yang ditujukan ke responden. Tujuan pernyataan untuk mengetahui apakah responden belum bisa membaca tulisan Bahasa dengan baik dan benar. Persentase dari jumlah responden untuk butir 16, sebanyak $13.5 \%$ atau 5 responden memilih jawaban sangat setuju. Sebanyak $35.1 \%$ atau 13 responden memilih jawaban setuju. Sebanyak $37.8 \%$ atau 14 responden memilih jawaban tidak setuju, sedangkan pilihan jawaban sangat tidak setuju dipilih sebanyak $13.5 \%$ atau 5 responden. Total dari keempat jawaban adalah $100 \%$, artinya semua responden menjawab butir 16 dan valid datanya. Kesimpulannya adalah sebanyak $37.84 \%$ responden tidak setuju dengan pernyataan butir 16 kuisioner. Artinya responden sudah mampu membaca tulisan Bahasa dengan baik dan benar.

\section{Butir 17 (Fav)}

Butir 17 merupakan pernyataan positif yang ditujukan ke responden. Tujuan pernyataan untuk mengetahui apakah responden paham inti atau garis besar makna kalimat dari sebuah tulisan berBahasa. Persentase dari jumlah responden untuk butir 17, sebanyak $18.9 \%$ atau 7 responden memilih jawaban setuju. Lebih dari separuh responden yaitu $64.9 \%$ atau 24 responden memilih jawaban tidak setuju. Sebanyak 16.2\% atau 6 responden memilih jawaban sangat tidak setuju, sedangkan jawaban sangat setuju tidak ada seorang respondenpun yang 
memilihnya. Total dari ketiga jawaban adalah 100\%, artinya semua responden menjawab butir 17 dan valid datanya. Keimpulannya, sebanyak $64.86 \%$ atau lebih dari separuh responden tidak setuju dengan pernyataan butir 17 kuisioner. Artinya lebih dari separuh responden mengatakan tidak paham inti atau garis besar makna kalimat dari sebuah tulisan berBahasa.

\section{b. Analisa Kemampuan Menulis}

Ke 9 butir tersebut terbagi masing-masing menjadi 5 butir favorable dan 4 butir unfavorable. Butir favorable ditunjukkan pada pernyataan butir 8, 28, 30, 33, dan 35. Butir unfavorable ditunjukkan pada butir 29, 31, 32, dan $34^{12}$. Berikut ini adalah analisis kuantitatif deskriptif berdasarkan jawaban responden untuk setiap butir.

\section{Butir 8 (Fav)}

Butir 8 merupakan pernyataan positif yang ditujukan ke responden. Tujuan pernyataan untuk mengetahui apakah responden mencatat kata-kata baru atau kosa kata baru Bahasa yang responden dengarkan atau baca. Hasil pengolahan SPSS adalah sebanyak 8.1\% atau 3 responden memilih jawaban setuju. Lebih dari separuh responden yaitu sebanyak 54.1\% atau 20 responden memilih jawaban tidak setuju. Sebanyak 37.8\% atau 14 responden memilih jawaban sangat tidak setuju, sedangkan jawaban sangat setuju tidak ada seorangpun responden yang memilih. Total dari ketiga jawaban adalah 100\%, artinya semua responden menjawab butir 8 dan valid datanya. Kesimpulan adalah sebanyak $54.05 \%$ atau lebih dari separuh responden tidak setuju dengan pernyataan butir 8 kuisioner. Artinya responden tidak mencatat kata-kata baru atau kosa kata baru menggunakan Bahasa yang responden dengarkan atau baca.

\section{Butir 28 (Fav)}

Butir 28 merupakan pernyataan positif yang ditujukan ke responden. Tujuan pernyataan untuk mengetahui apakah responden mampu menulis kalimat menggunakan Bahasa. Presentase dari butir 28 adalah sebanyak $18.9 \%$ atau 7 responden memilih jawaban setuju. Lebih dari separuh responden yaitu sebanyak $59.5 \%$ atau 22 responden memilih jawaban tidak setuju. Sebanyak 21.6\% atau 8 responden memilih jawaban sangat tidak setuju, sedangkan jawaban sangat setuju tidak ada seorang respondenpun yang memilihnya. Total dari ketiga jawaban adalah $100 \%$, artinya semua responden menjawab butir 28 dan valid datanya. Kesimpulan adalah sebanyak $59.46 \%$ atau lebih dari separuh responden tidak setuju dengan pernyataan butir 28 kuisioner. Artinya lebih dari separuh responden mengatakan responden tidak atau belum mampu menulis kalimat menggunakan Bahasa.

\section{Butir 29 (Unfav)}

Butir 29 merupakan pernyataan negatif yang ditujukan ke responden. Tujuan pernyataan untuk mengetahui apakah menurut responden dosen (baik dosen Bahasa ataupun dosen mata kuliah lain) jarang memberikan tugas tertulis. Sebanyak $10.8 \%$ atau 4 responden memilih jawaban sangat setuju. Sebanyak $32.4 \%$ atau 12 responden memilih jawaban setuju. Hampir

12 Maya Rini. Handayani [2017] Pengaruh Kemampuan Berbahasa Indonesia terhadap Keberhasilan Studi Mahasiswa Pattani Thailand Selatan di UIN Walisongo Semarang. Laporan Penelitian Individual dibiayai dengan Anggaran DIPA LP2M UIN Walisongo Semarang tahun 2017. hal. 29 
separuh responden yaitu sebanyak $40.5 \%$ atau 15 responden memilih jawaban tidak setuju, sedangkan sangat tidak setuju dipilih 6 responden atau 18.2\%. Total dari keempat jawaban adalah $100 \%$, artinya semua responden menjawab butir 29 dan valid datanya. Kesimpulannya, sebanyak $40.54 \%$ atau hampir dari separuh responden tidak setuju dengan pernyataan butir 29 kuisioner. Artinya hampir dari separuh responden mengatakan menurut responden dosen (baik dosen Bahasa ataupun dosen mata kuliah lain) sering memberikan tugas tertulis.

\section{Butir 30 (Fav)}

Butir 30 merupakan pernyataan positif yang ditujukan ke responden. Tujuan pernyataan untuk mengetahui apakah menurut responden tugas tertulis yang diberikan oleh dosen selalu diberi nilai oleh dosen dan dikembalikan pada mahasiswa. Sebanyak $27 \%$ atau 10 responden memilih jawaban setuju. Lebih dari separuh responden yaitu sebanyak 59.5\% atau 22 responden memilih jawaban tidak setuju. Sebanyak $13.5 \%$ atau 5 responden memilih jawaban sangat tidak setuju, sedangkan jawaban sangat setuju tidak ada seorangpun yang memilihnya. Total dari ketiga jawaban adalah 100\%, artinya semua responden menjawab butir 30 dan valid datanya. Kesimpulan bahwa sebanyak $59.46 \%$ atau lebih dari separuh responden tidak setuju dengan pernyataan butir 30 kuisioner. Artinya lebih dari separuh responden mengatakan tugas tertulis yang diberikan oleh dosen tidak selalu dinilai oleh dosen dan tidak selalu dikembalikan pada mahasiswa.

\section{Butir 31 (Unfav)}

Butir 31 merupakan pernyataan negatif yang ditujukan ke responden. Tujuan pernyataan untuk mengetahui apakah responden jarang mengevaluasi atau menilai diri sendiri atas hasil ujian yang dikembalikan. Sebanyak $2.7 \%$ atau 1 responden memilih jawaban sangat setuju. Sebanyak $37.8 \%$ atau 14 responden memilih jawaban setuju. Lebih dari separuh responden yaitu sebanyak $54.1 \%$ atau 20 responden memilih jawaban tidak setuju, sedangkan jawaban sangat tidak setuju dipilih sebanyak $5.4 \%$ atau 2 responden. Total dari keempat jawaban adalah $100 \%$, artinya semua responden menjawab butir 31 dan valid datanya. Kesimpulan bahwa sebanyak $54.05 \%$ atau lebih dari separuh responden tidak setuju dengan pernyataan butir 31 kuisioner. Artinya lebih dari separuh responden mengatakan responden sering mengevaluasi atau menilai diri sendiri atas hasil ujian yang dikembalikan.

\section{Butir 32 (Unfav)}

Butir 32 merupakan pernyataan negatif yang ditujukan ke responden. Tujuan pernyataan untuk mengetahui apakah responden belum bisa membuat kalimat dengan menggunakan Bahasa. Sebanyak $2.7 \%$ atau 1 responden memilih jawaban sangat setuju. Sebanyak $18.9 \%$ atau 7 responden memilih jawaban setuju. Hampir tiga perempat responden yaitu sebanyak $70.3 \%$ atau 26 responden memilih jawaban tidak setuju, sedangkan sebanyak $8.1 \%$ atau 3 responden memilih jawaban sangat tidak setuju. Total dari keempat jawaban adalah $100 \%$, artinya semua responden menjawab butir 32 dan valid datanya. Kesimpulan bahwa sebanyak $70.27 \%$ atau hampir tiga perempat responden tidak setuju dengan pernyataan butir 32 kuisioner. Artinya 
hampir tiga perempat responden sudah bisa membuat kalimat dengan menggunakan Bahasa.

\section{Butir 33 (Fav)}

Butir 33 merupakan pernyataan positif yang ditujukan ke responden. Tujuan pernyataan untuk mengetahui apakah responden sering mengutip (menulis ulang) kalimat dari sebuah buku berBahasa. Sebanyak 51.4\% atau 19 responden memilih jawaban setuju. Sebanyak 35.1\% atau 13 responden memilih jawaban tidak setuju. Sebanyak $13.5 \%$ atau 5 responden memilih jawaban sangat tidak setuju, sedangkan pilihan jawaban sangat setuju tidak ada seorang respondenpun yang memilih. Total dari ketiga jawaban adalah $100 \%$, artinya semua responden menjawab butir 33 dan valid datanya. Kesimpulan bahwa sebanyak 51.35\% atau lebih dari separuh responden setuju dengan pernyataan butir 33 kuisioner. Artinya lebih dari separuh responden sering mengutip (menulis ulang) kalimat dari sebuah buku berBahasa.

\section{Butir 34 (Unfav)}

Butir 34 merupakan pernyataan negatif yang ditujukan ke responden. Tujuan pernyataan untuk mengetahui apakah responden kurang mampu menuliskan inti atau garis besar dari sebuah tulisan berBahasa. Sebanyak $8.1 \%$ atau 3 responden memilih jawaban sangat setuju. Lebih dari separuh responden yaitu sebanyak $56.8 \%$ atau 21 responden memilih jawaban setuju. Sebanyak 35.1\% atau 13 responden memilih jawaban tidak setuju, sedangkan pilihan jawaban sangat tidak setuju tidak ada seorang respondenpun yang memilih. Total dari ketiga jawaban adalah $100 \%$, artinya semua responden menjawab butir 34 dan valid datanya. Kesimpulan bahwa sebanyak $56.76 \%$ atau lebih dari separuh responden setuju dengan pernyataan butir 34 kuisioner. Artinya lebih dari separuh responden kurang mampu menuliskan inti atau garis besar dari sebuah tulisan berBahasa.

\section{Butir 35 (Fav)}

Butir 35 merupakan pernyataan positif yang ditujukan ke responden. Tujuan pernyataan untuk mengetahui apakah responden mampu merangkum materi kuliah menggunakan tulisan Bahasa. Sebanyak 24.3\% atau 9 responden memilih jawaban setuju. Lebih dari separuh responden yaitu sebanyak $56.8 \%$ atau 21 responden memilih jawaban tidak setuju. Sebanyak $18.9 \%$ atau 7 responden memilih jawaban sangat tidak setuju, sedangkan pilihan jawaban sangat setuju tidak ada seorang respondenpun yang memilih. Total dari ketiga jawaban adalah $100 \%$, artinya semua responden menjawab butir 35 dan valid datanya. Kesimpulan bahwa sebanyak $56.76 \%$ atau lebih dari separuh responden tidak setuju dengan pernyataan butir 35 kuisioner. Artinya lebih dari separuh responden tidak atau belum mampu merangkum materi kuliah menggunakan tulisan Bahasa.

\section{Temuan Hasil Penulisan}

Pada pembahasan artikel ini mencakup 2 temuan hasil. Hal ini disebabkan indikator yang digunakan sebagai dasar acuan penelitian ada 2. Sebagaimana dijelaskan dalam pembahasan, indikator yang digunakan adalah kemampuan membaca dan menulis, maka berikut ini 
penjelasan hasil temuan berdasarkan indikator tersebut.

\section{Temuan Hasil Kemampuan Membaca}

Analisa deskriptif digunakan untuk mengetahui persentase setiap butir pernyataan sesuai dengan indikator yang digunakan. Meskipun demikian, analisa tersebut belumlah bisa digunakan untuk menarik sebuah kesimpulan dari penelitian ini. Penelitian ini bertujuan mencari seberapa baikkah kemampuan responden dalam membaca tulisan BerBahasa. Untuk menjawab pertanyaan tersebut maka dicarilah mean (rata-rata) dan standar deviasi dari nilai total butir pernyataan untuk indikator membaca. Pencarian penghitungan mean dan standar deviasi menggunakan bantuan SPSS ver. 16, hasilnya seperti pada tabel di bawah ini :

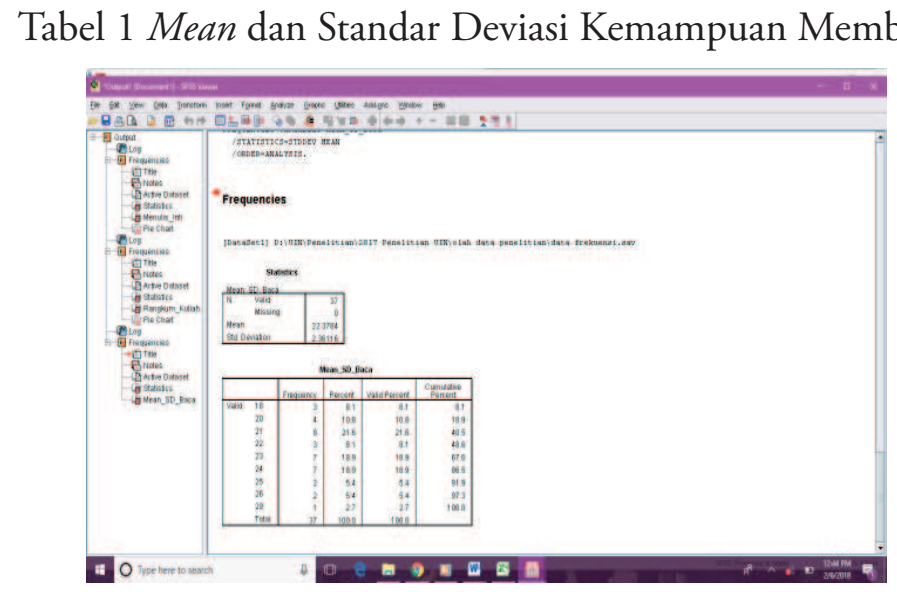

Dari tabel di atas terlihat $\mathrm{N}$ sebanyak 37 responden, mean sebesar 22.3784 yang kemudian dibulatkan menjadi 22. Standar deviasi yang ditemukan adalah sebesar 2.36116 yang dibulatkan menjadi 2.4. Hasil mean dan standar deviasi digunakan sebagai acuan untuk membuat interval standar lima ${ }^{13}$. Interval diukur dengan menggunakan rumus seperti yang terlihat pada tabel di bawah ini:

Tabel 2 Perhitungan Interval Kemampuan Membaca

\begin{tabular}{|l|l|}
\hline \multicolumn{1}{|c|}{ Rumus } & \multicolumn{1}{c|}{ Perhitungan } \\
\hline Mean $+1,5$ (Standar Deviasi) & $22+1,5(2.4)=26$ \\
\hline Mean $+0,5($ Standar Deviasi) & $22+0,5(2.4)=23$ \\
\hline Mean - 0,5 (Standar Deviasi) & $22-0,5(2.4)=21$ \\
\hline Mean - 1,5 (Standar Deviasi) & $22-1,5(2.4)=18$ \\
\hline
\end{tabular}

Tabel di atas memperlihatkan interval mean (rata-rata) kemampuan membaca dari ke 37 responden. Perhitungan menggunakan mean $+1,5$ (Standar Deviasi) diperoleh angka 26. Perhitungan ke 2 yaitu mean + 0,5 (Standar Deviasi) diperoleh 23. Perhitungan ke 3, mean 0,5 (Standar Deviasi) diperoleh 21, dan yang terakhir mean - 1,5 (Standar Deviasi) diperoleh 18. Dari perhitungan tersebut terlihat bahwa batas angka tertinggi adalah 26 dan batas angka terendah adalah 18 untuk kategorisasi standar lima. Artinya dari angka 18 hingga 26 adalah

13 Anas. Sudijono [2009] Pengantar Evaluasi Pendidikan. Jakarta: Rajawali Pres, Jakarta, hal. 452-453 
rentang atau interval yang akan digunakan untuk mengukur dan mengambil kesimpulan kemampuan responden dalam membaca tulisan berBahasa. Tabel berikut ini akan memperjelas interval kemampuan membaca responden yang telah diukur.

Tabel 3 Interval Kemampuan Membaca

\begin{tabular}{|c|c|c|}
\hline No & Interval & Kategori \\
\hline 1. & 26 ke atas & Sangat Tinggi \\
\hline 2. & $23-25$ & Tinggi \\
\hline 3. & $21-22$ & Sedang \\
\hline 4. & $19-20$ & Rendah \\
\hline 5. & 18 ke bawah & Sangat Rendah \\
\hline
\end{tabular}

Pada tabel di atas, interval diperoleh dari perhitungan tabel 14 dengan kategori sebanyak 5 standar. Mean dari indikator membaca pada penelitian ini sebesar 22 (perhatikan tabel 20). Apabila dibandingkan dengan interval pada tabel 22 maka akan terlihat bahwa angka 22 berada di antara angka 21 - 22 (baris ke 3). Rentang 21 - 22 menunjuk pada kategori sedang. Kesimpulan yang dapat diambil dari temuan hasil dari artikel ini adalah kemampuan membaca mahasiswa Thailand Selatan menggunakan Bahasa di UIN Walisongo Semarang berada pada kategori sedang.

\section{Temuan Hasil Kemampuan Menulis}

Temuan hasil berikutnya adalah menemukan seberapa baikkah kemampuan responden dalam menulis tulisan menggunakan Bahasa. Untuk menjawab pertanyaan tersebut maka dicarilah mean (rata-rata) dan standar deviasi untuk indikator menulis. Pencarian penghitungan menggunakan bantuan SPSS ver. 16, hasil perhitungan seperti pada tabel di bawah ini :

Tabel 4 Mean dan Standar Deviasi Kemampuan Menulis

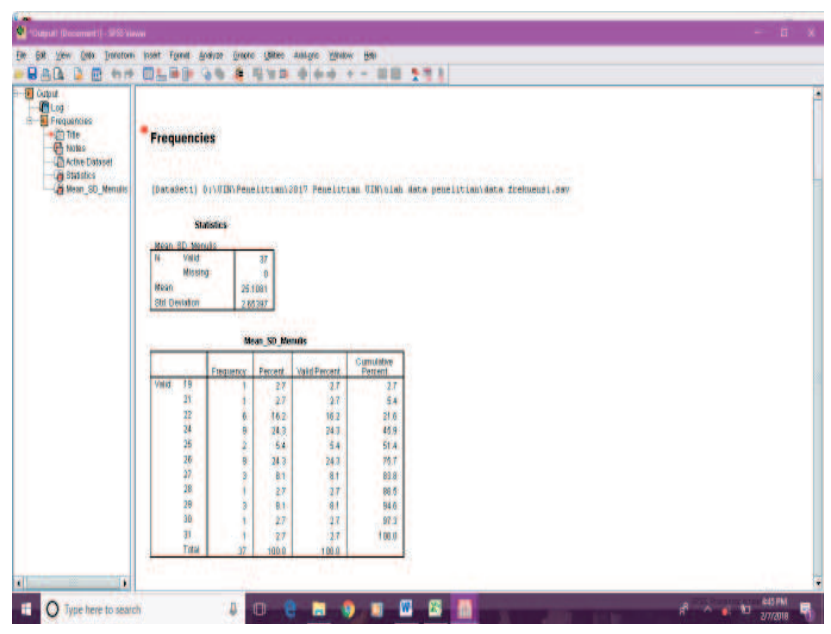

Dari tabel di atas terlihat $\mathrm{N}$ sebanyak 37 responden, mean sebesar 25.1081 yang kemudian dibulatkan menjadi 25. Standar deviasi yang ditemukan adalah sebesar 2.65397 yang dibulatkan menjadi 2.7. Sama seperti temuan hasil sebelumnya, hasil mean dan standar deviasi digunakan 
sebagai acuan untuk membuat interval standar lima. Interval diukur dengan menggunakan rumus seperti yang terlihat pada tabel di bawah ini :

Tabel 5 Perhitungan Interval Kemampuan Menulis

\begin{tabular}{|l|l|}
\hline \multicolumn{1}{|c|}{ Rumus } & \multicolumn{1}{c|}{ Perhitungan } \\
\hline Mean $+1,5$ (Standar Deviasi) & $25+1,5(2.7)=29$ \\
\hline Mean $+0,5$ (Standar Deviasi) & $25+0,5(2.7)=26$ \\
\hline Mean - 0,5 (Standar Deviasi) & $25-0,5(2.7)=24$ \\
\hline Mean - 1,5 (Standar Deviasi) & $25-1,5(2.7)=21$ \\
\hline
\end{tabular}

Tabel di atas memperlihatkan interval mean (rata-rata) kemampuan menulis Bahasa dari ke 37 responden. Perhitungan menggunakan mean $+1,5$ (Standar Deviasi) diperoleh angka 29. Perhitungan ke 2 yaitu mean $+0,5$ (Standar Deviasi) diperoleh 26. Perhitungan ke 3, mean 0,5 (Standar Deviasi) diperoleh 24, dan yang terakhir mean - 1,5 (Standar Deviasi) diperoleh 21. Dari perhitungan tersebut terlihat bahwa batas angka tertinggi adalah 29 dan batas angka terendah adalah 21 untuk kategorisasi standar lima. Artinya dari angka 21 hingga 29 adalah rentang atau interval yang akan digunakan untuk mengukur dan mengambil kesimpulan kemampuan responden dalam menulis tulisan berBahasa. Tabel berikut ini akan memperjelas interval kemampuan menulis Bahasa responden yang telah diukur.

Tabel 6 Interval Kemampuan Menulis

\begin{tabular}{|c|c|c|}
\hline No & Interval & Kategori \\
\hline 1. & 29 ke atas & Sangat Tinggi \\
\hline 2. & $26-28$ & Tinggi \\
\hline 3. & $24-25$ & Sedang \\
\hline 4. & $22-23$ & Rendah \\
\hline 5. & 21 ke bawah & Sangat Rendah \\
\hline
\end{tabular}

Pada tabel di atas, interval diperoleh dari perhitungan tabel 24 dengan kategori sebanyak 5 standar. Mean dari indikator menulis pada artikel ini sebesar 25 (perhatikan tabel 23). Apabila dibandingkan dengan interval pada tabel 25 maka akan terlihat bahwa angka 25 berada di antara angka $24-25$ (baris ke 3). Rentang $24-25$ menunjuk pada kategori sedang. Kesimpulan yang dapat diambil dari temuan hasil artikel ini adalah kemampuan menulis mahasiswa Thailand Selatan di UIN Walisongo Semarang menggunakan Bahasa berada pada kategori sedang.

\section{E. Penutup}

Berdasarkan pembahasan dan temuan hasil penelitian artikel ini dapat disimpulkan bahwa kemampuan membaca dan menulis mahasiswa Thailand Selatan menggunakan Bahasa berada pada kategori sedang. Artinya rata-rata mahasiswa Thailand yang kuliah di UIN Walisongo cukup mampu untuk membaca dan menulis dengan menggunakan Bahasa. Mahasiswa Thailand Selatan hendaknya lebih meningkatkan belajar utuk membaca dan menulis Bahasa agar kemampuan Bahasa meningkat hingga berada di kategori tinggi. 


\section{Bibliografi}

Anonim, 2017, "Pattani Thailand", https://en.wikipedia.org/wiki/Pattani,_Thailand, diakses 24 Februari 2017

Arikunto, Suharsimi, 2002, "Prosedur Penulisan Suatu Pendekatan Praktek", PT Renaka Cipta, Jakarta

Anonim, 2017, "Propinsi Yala", di akses melalui https://id.wikipedia.org/wiki/Propinsi_Yala, pada 18 Oktober 2017.

Anonim, 2017, "Wilayah Pattani”, di akses melalui https://ms.wikipedia.org/wiki/Wilayah_ Pattani, pada 18 Oktober 2017.

Anonim, 2017, “Propinsi Satun”, di akses melalui https://id.wikipedia.org/wiki/Propinsi_Satun, pada 18 Oktober 2017.

Handayani, Maya Rini, 2014, The Role of Information Technology in Islamic Da'wa Student Development at Pondok Bantan Nakhon Si Thammarat Southern Thailand, ISBN 978602-17171-9-6.

Handayani, Maya Rini, 2017, "Pengaruh Kemampuan Berbahasa Indonesia terhadap Keberhasilan Studi Mahasiswa Pattani Thailand Selatan di UIN Walisongo Semarang”, Laporan Penelitian Individual dibiayai dengan Anggaran DIPA LP2M UIN Walisongo Semarang tahun 2017, hal. 37

Yusuf, Muri, 2014, Metode Penulisan Kuantitatif, Kualitatif dan Penulisan Gabungan, Jakarta: Prenada Media Group, hal 144

Sugiyono, 2005, Statistika untuk Penelitian, CV. Alfabeta, Bandung

Sugiyono, 2007, Metode Penelitian Pendidikan (Pendekatan Kuantitatif, Kualitatif dan R\&D, Alfabeta, Bandung

Sugiyono, 2011, Metode Penelitian Kuantitatif Kualitatif dan R\&D, Alfabeta, Bandung

Sugiyono, 2014, Statistika Untuk Penelitian, Alfabeta, Bandung

Sudijono, Anas, 2009, Pengantar Evaluasi Pendidikan, Rajawali Pres, Jakarta. 